\title{
Assessing Approaches of Human Inhalation Exposure to Polycyclic Aromatic Hydrocarbons: A Review
}

\author{
Xuan Zhang ${ }^{1}{ }^{\oplus}$, Lu Yang ${ }^{1}$, Hao Zhang ${ }^{1}$, Wanli Xing ${ }^{1}$, Yan Wang ${ }^{1}$, Pengchu Bai ${ }^{1}{ }^{1}$, Lulu Zhang ${ }^{2}$, \\ Kazuichi Hayakawa ${ }^{2}$, Akira Toriba ${ }^{3}$, Yongjie Wei ${ }^{4, *}$ and Ning Tang ${ }^{2,5, *}$ (1)
}

1 Graduate School of Medical Sciences, Kanazawa University, Kakuma-machi, Kanazawa 920-1192, Japan; zhangxuan@stu.kanazawa-u.ac.jp (X.Z.); veronicayl@stu.kanazawa-u.ac.jp (L.Y.); zhanghao@stu.kanazawa-u.ac.jp (H.Z.); xingwanli@stu.kanazawa-u.ac.jp (W.X.); wangyan@stu.kanazawa-u.ac.jp (Y.W.); baipengchu@stu.kanazawa-u.ac.jp (P.B.)

2 Institute of Nature and Environmental Technology, Kanazawa University, Kakuma-machi, Kanazawa 920-1192, Japan; zhang-lulu@se.kanazawa-u.ac.jp (L.Z.); hayakawa@p.kanazawa-u.ac.jp (K.H.)

3 School of Pharmaceutical Sciences, Nagasaki University, Bunkyo-machi, Nagasaki 852-8521, Japan; toriba@nagasaki-u.ac.jp

4 State Key Laboratory of Environmental Criteria and Risk Assessment, Chinese Research Academy of Environment Sciences, Beijing 100012, China

5 Institute of Medical, Pharmaceutical and Health Sciences, Kanazawa University, Kakuma-machi, Kanazawa 920-1192, Japan

* Correspondence: weiyj@craes.org.cn (Y.W.); n_tang@staff.kanazawa-u.ac.jp (N.T.); Tel.: +81-76-234-4455 (N.T.)

\section{check for} updates

Citation: Zhang, X.; Yang, L.; Zhang, H.; Xing, W.; Wang, Y.; Bai, P.; Zhang, L.; Hayakawa, K.; Toriba, A.; Wei, Y.; et al. Assessing Approaches of Human Inhalation Exposure to Polycyclic Aromatic Hydrocarbons: A Review. Int. J. Environ. Res. Public Health 2021, 18, 3124. https:// doi.org/10.3390/ijerph18063124

Academic Editors: Paul B. Tchounwou and Jung-Hwan Kwon

Received: 6 March 2021

Accepted: 16 March 2021

Published: 18 March 2021

Publisher's Note: MDPI stays neutral with regard to jurisdictional claims in published maps and institutional affiliations.

Copyright: (c) 2021 by the authors. Licensee MDPI, Basel, Switzerland. This article is an open access article distributed under the terms and conditions of the Creative Commons Attribution (CC BY) license (https:// creativecommons.org/licenses/by/ $4.0 /)$.
Abstract: Polycyclic aromatic hydrocarbons (PAHs) are a class of important organic pollutants widely emitted from anthropogenic activities, with a general distribution in the gas and particulate phases. Some PAHs are carcinogenic, teratogenic, and mutagenic. Inhalation exposure to PAHs is correlated with adverse health outcomes in the respiratory and cardiovascular systems. Thus, it is significant to determine the exposure level of the general population. This study summarizes the evaluation methods for PAH exposure, focusing on different exposure parameters. External exposure can be determined via the collection of the environmental pollution concentration through active samplers or passive samplers during environmental monitoring or personal sampling. Time-activity patterns give critical exposure information that captures the exposure period, origin, and behaviors. Modeling is a labor-less approach for human exposure estimation, and microenvironmental exposure requires specific research. It is important to select appropriate methods to quantify the exposure level to provide accurate data to establish the exposure-risk relationship and make scientific suggestions for the protection of public health.

Keywords: polycyclic aromatic hydrocarbon; human exposure; time-activity patterns; modeling

\section{Introduction}

Polycyclic aromatic hydrocarbons (PAHs) are a large class of persistent organic compounds (over 100 species) composed of two or more fused aromatic rings. PAHs are generated from the incomplete combustion of organic materials [1-6], which widely involve natural sources, such as volcano eruptions and forest fires, and anthropogenic activities as a dominant contributor, such as factory emissions, vehicle exhaust, residential heating, and environmental tobacco smoking [7-11].

PAHs have attracted great attention due to their adverse effects on human health. Some species are characterized with carcinogenicity, teratogenicity, and genotoxicity [12]. The International Agency for Research on Cancer Monographs Program has listed the carcinogenicity of 60 individual PAHs [13]. Among them, benzo[a]pyrene (BaP) is classified in Group 1 as a carcinogen to humans. Cyclopenta $[c, d]$ pyrene (CPP), dibenz $[a, h]$ anthracene (DBA), and dibenzo $[a, l]$ pyrene (DlP) are listed in Group 2A with probable carcinogenicity to humans. Benz[j]aceanthrylene, benz $[a]$ anthracene $(\mathrm{BaA})$, benzo $[b]$ fluoranthene $(\mathrm{BbF})$, 
benzo[j]fluoranthene $(\mathrm{BjF})$, benzo[ $k]$ fluoranthene $(\mathrm{BkF})$, benzo[c]phenanthrene, chrysene $(\mathrm{Chr})$, dibenzo $[a, h]$ pyrene $(\mathrm{DhP})$, dibenzo[ $[a, i]$ pyrene (DiP), indeno[1,2,3-cd]pyrene (IDP), and 5-methylchrysene (5MC) are classified as possibly carcinogenic to humans (Group 2B). On the other hand, short/long-term PAH exposure can induce and strengthen respiratory symptoms and airway illnesses such as asthma, chronic obstructive pulmonary diseases, and even cancers [14-17]. PAH exposure is also correlated with reproductive dysfunction [18-20]. Prenatal exposure to PAHs could lead to several birth defects [21-23]. The U.S. Environmental Protection Agency listed 16 PAHs as the primary control pollutants, including naphthalene (Nap), acenaphthylene (Acy), acenaphthene (Ace), fluorene (Fle), phenanthrene (Phe), anthracene (Ant), fluoranthene (FR), pyrene (Pyr), BaA, $\mathrm{Chr}, \mathrm{BbF}$, BkF, BaP, DBA, benzo[ghi]perylene (BghiP) and IDP [24]. The European Union classified $15+1$ PAH species as priorities in food, involving benzo[c]fluorene $(\mathrm{BcF}), \mathrm{BaA}, \mathrm{CPP}, \mathrm{Chr}$, $5 \mathrm{MC}, \mathrm{BbF}, \mathrm{BjF}, \mathrm{BkF}, \mathrm{BaP}$, BghiP, DBA, IDP, dibenzo[a,e]pyrene (DeP), DhP, DiP, and DlP [25]. Moreover, due to a strong carcinogenicity, an environmental standard was set for the ambient level of BaP in some countries, such as a 24-h standard of $2.5 \mathrm{ng} / \mathrm{m}^{3}$ and an annual standard of $1.0 \mathrm{ng} / \mathrm{m}^{3}$ in China [26] and an annual level of $1.0 \mu \mathrm{g} / \mathrm{m}^{3}$ as a target value in Europe [27].

PAHs are ubiquitously distributed in the particulate and gaseous phases in the atmosphere, defined by their physiochemical properties, and impacted by meteorological conditions. Generally, low molecular weight PAHs (LMW-PAHs) with 2-3 rings are abundant in the gaseous phase. Four-ring PAHs with middle molecular weights (MMW-PAHs) are distributed in both phases with the influence of meteorological parameters. Five- and six-ring PAHs (HMW-PAHs) with high molecular weights are prone to exist in the particulate phase. Furthermore, particulate PAHs show different size distributions in particulate matter (PM); that is, freshly emitted PAHs are prone to distribute in finer size modes than those in ambient air [28]. In addition, PAHs can have a negative effect not only on local sites but also on downwind sites during long-range transport due to their long atmospheric lifetime [29-34]. The heterogeneous distribution and human health risk of PAHs indicates the importance of exploring the bodily burden and establishing an exposure-risk relationship.

Humans are exposed to PAHs through inhalation and oral and dermal pathways. According to the World Health Organization (WHO) [35], air pollution exposure was related to 4.2 million deaths in 2016, indicating an urgency for human exposure evaluation to air pollutants. The daily intake volume of air is 3.6 to $16.3 \mathrm{~m}^{3}$ for different age groups [36], suggesting a continuous and stable air pollution exposure of the public via inhalation. On the other hand, the oral route is related to life habits such as eating contaminated food. Dermal exposure also results from contaminated air while it is restricted by effective contact area and infiltration rate. Furthermore, inhalation exposure can directly pose an adverse effect on human respiratory system, which requires an accurate assessment.

Generally, the impact of environmental factors on human health is quantitatively evaluated by an exposure-response function in epidemiological studies. This function includes three key points: an accurate exposure dose, a clear health outcome intensity, and a scientific statistical analysis. The induced health effect is determined by the exposure length, route, PAH concentration, and toxicity, which should be clarified to evaluate its biological efficiency [37]. The current research has summarized and evaluated the most commonly used PAH exposure evaluation methods via inhalation based on their principles, advantages and disadvantages.

\section{Evaluation Method}

According to the study objectives, appropriate measuring methods should be selected and designed to reflect the actual exposure status of targeted individuals and a larger population within a reasonable range. In exposure evaluation studies, two kinds of exposures are typically characterized and measured (Figure 1), which are external and internal exposure according to the exposure stage. 


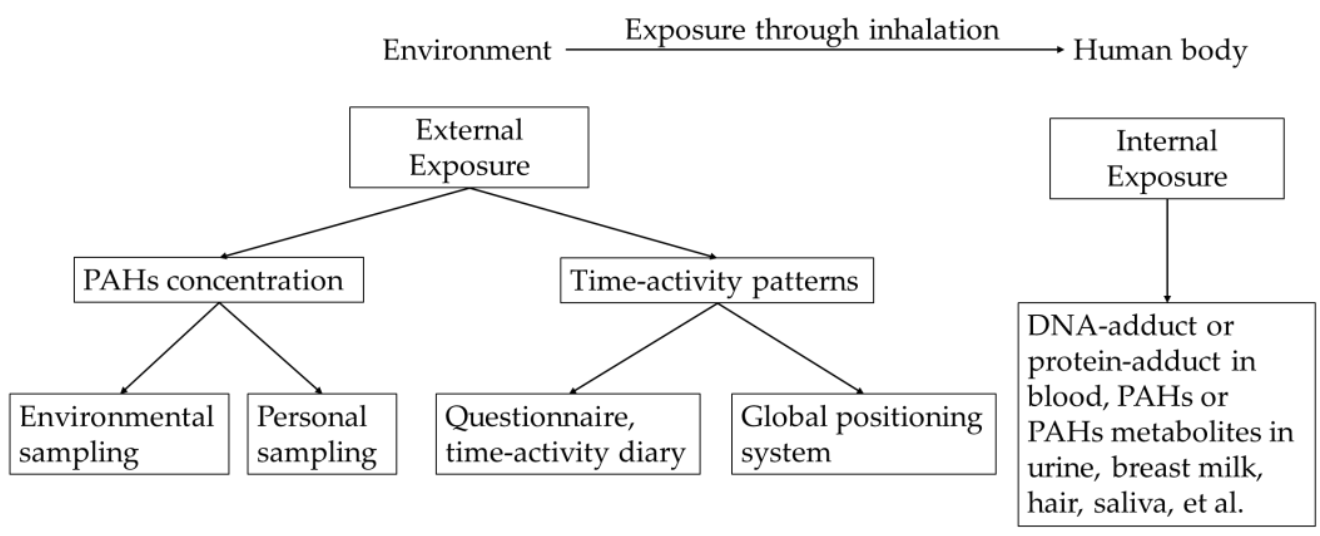

Figure 1. Flow chart of evaluation methods for polycyclic aromatic hydrocarbons (PAHs) exposure.

External exposure (Figure 1) is the air pollution concentration level of the environment where people dwell for a period, and can describe the exposure situation of individuals or populations. The exposure level can be directly estimated or predicted by modeling work based on pollution-related data and human time-activity patterns. Pollution-related data include the concentration of PAHs and impacting factors such as the meteorological index [38]. Basically, external exposure can be obtained by environmental sampling (conducted with fixed monitors) and individual-based measuring methods (conducted by personal mobile monitors) or a combination with active or passive samplers. In addition, the exposure period and behaviors are generally obtained by questionnaire and time-activity diary. The daily time-location patterns of subjects can also be tracked by a global positioning system.

The exposure level $\left(C_{i}\right)$ in a specific location is the result of the measured level multiplied by the respective dwelling time $\left(t_{\mathrm{i}}\right)$. The total exposure level $(\mathrm{C})$ is the sum of a series of microenvironmental exposures as follows (Equation (1)):

$$
C=\sum C_{i} \times t_{i}
$$

The average daily dose (ADD) by inhalation during the short- and long-term exposure can be estimated by combining a series of exposure parameters as in Equation (2) [39], in which IR is the inspiration rate, $\mathrm{m}^{3} / \mathrm{d}$ or $\mathrm{kg} / \mathrm{d}$; ET is the exposure time, $\mathrm{h} / \mathrm{d}$; EF is the exposure frequency, $\mathrm{d} / \mathrm{a}$; $\mathrm{ED}$ is the exposure duration, a; BW is the body weight; and AT is the average exposure time. In addition to calculating the sum of the microenvironmental exposure, the respiratory exposure can be further refined into the exposure dose during different activities because the difference in the intensity of the activity will cause the difference in the respiratory volume [40] (Equation (2)).

$$
\mathrm{ADD}=\mathrm{C} \times \mathrm{IR} \times \mathrm{ET} \times \mathrm{EF} \times \mathrm{ED} / \mathrm{BW} / \mathrm{AT}
$$

Internal exposure (Figure 1) indicates the body-absorbed PAH dose and is closer to the biologically effective content. After being inhaled, some amounts of PAHs are excluded through behaviors of the respiratory system such as coughing and sneezing. The remaining PAHs can further enter the lung and other organs and go through the metabolism. The internal exposure of PAHs is commonly represented by the parent PAH or metabolite content in human body specimens such as blood [41-45], urine [46-51], hair [52-54], breast milk [55-57], and saliva [58-60]. Nevertheless, it should be noted that internal exposure is a reflection of all exposure pathways. It is hard to extract the contribution of each route [47] to trace the exposure source and behavior and further provide suggestions to target control measures. On the other hand, the baseline of internal PAHs exposure levels in the human body is critically impacted by individual lifestyles and metabolite capacity $[43,50]$, which makes it difficult to clarify the proportion of inhalation exposure. 
Thus, in this study, external exposure will be dominantly discussed, involving the methods to collect air pollutant concentration and other exposure-related data.

\subsection{Pollution-Related Data Based on Environmental Sampling}

Environmental sampling is conducted through one or several stationary samplers set in the surrounding environment of the target population during sampling periods.

Table 1 listed previous studies of PAHs exposure measured by stationary sampling. Ambient PAH levels can reflect the regional outdoor atmospheric conditions, which is the traditional data source used to evaluate the exposure level of the surrounding population. Pei et al. [61] collected the short-term exposure to PAH-bound particulate matter $\left(\mathrm{PM}_{2.5}\right)$ of 175 elderly adults by samplers set in 5 communities in Beijing; the PAH level exhibited mean values of 44.2 and $47.1 \mathrm{ng} / \mathrm{m}^{3}$ during two sampling periods. Wu et al. [62] measured PAH concentrations ranging from 0.8 to $18.3 \mathrm{mg} \mathrm{kg}^{-1}$ in the street dust obtained from bus stops to assess the exposure level of daily commuters. Ramírez et al. [63] monitored the concentration of 18 PAHs in particulate and gas phase in 3 nearby industry sites and found that the inhalation cancer risk of PAHs exposure for surrounding dwellers was $1.2 \times 10^{-4}$, which was 10 times higher than the guidelines suggested by the WHO.

The indoor air environment also has many sources, e.g., from cooking, cleaning, and domestic heating, which significantly contribute to human exposure [64]. Du et al. [65] detected elevated levels of $28 \mathrm{PAHs}$ in gaseous and particulate phases in the kitchen in rural households located in northern $\left(3132 \mathrm{ng} / \mathrm{m}^{3}\right)$ China, compared to southern China $\left(594 \mathrm{ng} / \mathrm{m}^{3}\right)$. In Xi'an, a northwestern city in China, He et al. [66] found a higher PAH concentration in the rural household conducting cooking by mixed-fuel than those using coal, which was 116 and $103 \mathrm{ng} / \mathrm{m}^{3}$, respectively. In Chen et al. [46], a high outdoor concentration level of 16 PAHs $\left(77.7 \mathrm{ng} / \mathrm{m}^{3}\right)$ was detected in a county near a coal chemistry factory, while a concentration level of $1.17 \mathrm{ng} / \mathrm{m}^{3}$ was detected in an agricultural county. However, the indoor level was the reverse. Zhu et al. [67] measured the indoor and outdoor PAHs concentration of an office in Jinan, China and found that office workers were 10 times more likely to be at risk of cancer in autumn than summer in both indoor and outdoor environments. In our previous studies, the exposure level of children in school environments in Beijing and Shanghai was investigated. The exposure level of 11 PAHs during the heating period was approximately 25 times higher than that during the non-heating period both indoors and outdoors in Beijing [68]. Levels of 9 PAHs were found to be approximately 4 times higher in the cold season than in the warm season at two urban and suburban elementary schools in Shanghai with no domestic heating activity [69]. Similarly, Chen et al. [70] measured higher PAH levels at an outdoor site $\left(61.2 \mathrm{ng} / \mathrm{m}^{3}\right)$ than its surrounding three indoor environments $\left(34.1 \mathrm{ng} / \mathrm{m}^{3}\right.$ at a students' dormitory, $32.1 \mathrm{ng} / \mathrm{m}^{3}$ at a residential home and $39.8 \mathrm{ng} / \mathrm{m}^{3}$ at an office) in urban Beijing. $\mathrm{PAH}$ concentration in ambient air was also elevated compared to the concurrent residential indoor levels in Hong Kong, which were 3.9 and $3.0 \mathrm{ng} / \mathrm{m}^{3}$, respectively [71].

Individuals have relatively stable time-location-activity patterns, which makes it reasonable to measure and combine microenvironmental exposures to estimate personal exposure in a statistical model. Place-based measurements can generate an exhaustive description of the specified environmental exposure to clarify the key sources, crucial PAH species, and human exposure behaviors, which is beneficial for providing scientific suggestions for standard formation. Moreover, this approach could lower the sampling burden of the subjects.

\subsection{Pollution-Related Data Based on Personal Sampling}

Personal sampling is participant-based; i.e., portable samplers with high spatial resolution are carried by the subjects during the sampling periods to describe individual variations rather than environmental variations in the exposure level. Portable instruments are commonly packed in a sampling box or backpack or pinned to the clothing according 
to the sampler weight and size. The air adsorbing part of the sampler is set near the respiratory location, aiming to collect the inhaled portion of the air.

Table 2 summarized previous studies of PAH exposure measured by personal sampling. Tonne et al. [72] measured the 48-h exposure of 9 PAHs by 348 pregnant females via an individual sampler, and the results indicated a mean value of $7.966 \mathrm{ng} / \mathrm{m}^{3}$. Mu et al. [73] observed a 1.0 to 2.5 higher exposure level of most PAHs in the Wuhan participants than in the Zhuhai participants in a large community-based cohort. Duan et al. [74] collected individual exposure samples of PAHs for 126 volunteers in Taiyuan. They found that the exposure level of 15 PAHs for rural residents was lower than that of urban residents in the non-heating season (404 and $312 \mathrm{ng} / \mathrm{m}^{3}$, respectively) while comparable in the heating season (690 and $770 \mathrm{ng} / \mathrm{m}^{3}$, respectively) due to enhanced household cooking and heating. Han et al. [75] measured the personal exposure level of 12 PAHs for a panel of 80 elderly, and clarified that the $44.1 \%$ of induced cancer risk from PAH exposure resulted from gasoline vehicle emission. Smargiassi et al. [76] conducted repeated daily measurements of 72 asthmatic children living in an industry-surrounding region, with samplers loaded in a small backpack, and found comparable exposure concentrations of LMW-PAHs (2-4 ring PAHs) and HMW-PAHs (5-6 ring PAHs) with mean values of 145.38 and $150.66 \mu \mathrm{g} / \mathrm{m}^{3}$, respectively. Fan et al. [77] performed personal sampling on 46 volunteers living in Hong Kong and detected a contribution of $46.8 \pm 13.4 \%$ of carcinogenic PAHs in the total 16 PAHs. Xu et al. [78] conducted personal sampling on subjects who were directly impacted by anthropogenic sources in an urbanizing region in southwest Africa and found that women's (exposed to the emission of domestic cooking and heating, $77.4 \mathrm{ng} / \mathrm{m}^{3}$ ) exposure concentration to 19 PAHs was 1.6 and 2.1 times that of students (exposed to waste burning discharge, $49.9 \mathrm{ng} / \mathrm{m}^{3}$ ) and drivers (exposed to vehicle emission, $37.0 \mathrm{ng} / \mathrm{m}^{3}$ ), respectively. Wei et al. [79] measured the 24-h PAH exposure level on security guards, which was mainly generated from vehicular emission, and found it was related to increasing oxidative burdens. Lovett et al. [80] measured the exposure level in four commuter routes by letting researchers carry samplers during the transport period. They found that the highest PAHs along a freeway $\left(0.940 \pm 0.346 \mathrm{ng} / \mathrm{m}^{3}\right)$ than a subway route, a light rail route, and high-density surface streets. Yan et al. [81] also detected the in-traffic exposure level by personal sampling and found that exposure in the bus mode $\left(99.6 \mathrm{ng} / \mathrm{m}^{3}\right)$ was higher than that in the walking mode $\left(77.8 \mathrm{ng} / \mathrm{m}^{3}\right)$ and subway mode $\left(46.3 \mathrm{ng} / \mathrm{m}^{3}\right)$.

Personal air monitoring is the most direct and accurate method for an external exposure measurement because it is not restricted to the spatial and temporal variations in atmospheric pollutants and personal activity. On the other hand, the accuracy of sampling is highly dependent on the participant's ability to correctly carry and protect and record possible instrument failure. The high cost, time consumption, and participation burden restrict its application to investigations with a small sample size and a specific type of population (reducing generalization), or a short term and/or range.

\subsection{Exposure Sampling Methods}

The external exposure level can be measured by active or passive air samplers according to the research need. Active samplers, which rely on the power of a pump to collect pollutant-containing air, can be divided into real-time or offline analysis samplers. A real-time sampler can generate concentration data because of its quick response to the captured PAHs, which can record abrupt exposure events [82-86]. However, this technique has poor accuracy with regard to the identification of individual species $[87,88]$. Active samplers with offline analysis capabilities commonly collect airborne PAHs with filters or sorbent materials. Particulate phase PAHs are suitable for collection with quartz filters, Teflon filters, and glass fiber filters, while polyurethane foam (PUF) and other sorbent materials (e.g., XAD-2, XAD-4, Carbopack C, and Tenax) are commonly employed for gasphase PAH capture [89]. After loading, PAHs are extracted from the collection materials and analyzed by techniques such as high-performance liquid chromatography and gas chromatography-mass spectrometry. Filter-based sampling can generate a comprehensive 
pollution profile with the characterization and specified quantification of individual and total PAHs, with multi-particulate sizes and particulate and gaseous phase distributions, as well as the simultaneous PM concentration and other PM-containing constituents if available $[72,73,78,81]$. Nevertheless, active samplers can burden users with pump noise and equipment weight.

Passive samplers typically contain an air receiving unit and a holder that collects the target constituents that rely on the molecular diffusion mechanism and the affinity of the absorbent to PAHs. Several adequate absorbent materials, such as silicone products and PUF and GC capillary integration units, were selected as passive samplers [90-96]. Silicone wristbands are light and pose no inconvenience to subjects who are in vulnerable or occupational groups, such as pregnant females and firefighters $[93,95,96]$. Passive samplers are inexpensive and user-friendly, and are more appropriate for gas-phase PAH sampling because particulate PAHs are not prone to diffuse into the gas phase due to a higher vapor pressure. Some researchers verified the sampling efficiency of passive sampling by the simultaneous active sampling data [97,98]. For example, Anderson et al. [98] tested the sampling performance of silicone wristband on 12 gas-phase PAHs by a simultaneous active sampling with a PUF cartridge (with the particulate PAHs collected by a quartz microfiber filter previously) in a personal sampling field work. They established a linear relationship between the PAH data captured by the wristband and PUF, indicating that air concentrations around the individual can be estimated by multiplying the partitioning coefficient with concentration data measured by the passive sampler. Nevertheless, research on the passive sampler capturing particulate PAHs is still lacking. Thus, prior to general application of the passive sampler, the collection performance, storage availability (PAH loss due to atmospheric reactions and molecular diffusion), and availability for chemical analysis (accurate extraction and purification) should be ensured in laboratory experiments and verified by comparison with active sampling in field studies.

\subsection{Time-Activity Patterns}

Time-activity patterns of the targeting population contain important exposure elements such as the time, location, and activity [99]. A questionnaire is a conventional and low-cost method with general applicability that can provide a detailed personal trajectory containing the location and duration related to exposure sources and activity during a sampling period. Additionally, a questionnaire can obtain a qualitative description of the exposure level through some targeted questions related to, for example, the cooking fuel, the cooking style, the number of cigarettes smoked, and the length of a smoking period $[78,100]$. However, this approach relies on participants that use field-dependent recall or hand-written diaries, which are completed every sampling day. Additionally, this method exhibits a memory bias, a high user burden, and a restriction in time resolution (usually 15-30 min). Some studies have utilized a Global Positioning System (GPS) system to mark dwelling environments by using a portable logger co-packed with samplers or a smart phone application, which can reduce the anthropogenic bias and improve data sensitivity [101,102]. This method can provide more detailed geological information but requires stable technological support and scientific time span division and integration with human activity. 
Table 1. Previous studies of PAH exposure measured by stationary sampling.

\begin{tabular}{|c|c|c|c|c|}
\hline Subjects & PAHs Phase and Number & Sampler Type & Site & Area \\
\hline Older adults [61] & 16 PAHs in $\mathrm{PM}_{2.5}$ & Active sampler & Communities & Beijing, China \\
\hline Commuter [62] & 16 PAHs in dust & Direct collection & Bus stops & Qingyang, China \\
\hline Residents [63] & $\begin{array}{l}18 \text { PAHs in PM and gas } \\
\text { phases }\end{array}$ & Active sampler & Ambient sites & Tarragona area, Europe \\
\hline Residents [64] & $\begin{array}{l}28 \text { PAHs in PM and gas } \\
\text { phases }\end{array}$ & Active sampler & $\begin{array}{l}\text { Indoor and outdoor of } \\
\text { rural residences }\end{array}$ & Shandong, China \\
\hline Residents [65] & $\begin{array}{l}28 \text { PAHs in PM and gas } \\
\text { phases }\end{array}$ & Active sampler & $\begin{array}{l}\text { Indoor and outdoor of } \\
\text { rural residences }\end{array}$ & $\begin{array}{l}\text { Shanxi and Guizhou, } \\
\text { China }\end{array}$ \\
\hline Residents [66] & 19 PAHs in PM & Active sampler & Indoor of residences & Xi'an, China \\
\hline Residents [46] & 16 PAHs in and gas phases & Active sampler & $\begin{array}{l}\text { Indoor and outdoor of } \\
\text { residences }\end{array}$ & Northern China \\
\hline Office workers [67] & 15 PAHs in $\mathrm{PM}_{2.5}$ & Active sampler & $\begin{array}{c}\text { Indoor and outdoor of an } \\
\text { office }\end{array}$ & Jinan, China \\
\hline Schoolchildren [68] & 11 PAHs in $\mathrm{PM}_{2.5}$ & Active sampler & $\begin{array}{l}\text { Indoor and outdoor of a } \\
\text { school }\end{array}$ & Beijing, China \\
\hline Schoolchildren [69] & 9 PAHs in $\mathrm{PM}_{2.1}$ & Active sampler & $\begin{array}{l}\text { Outdoor of two primary } \\
\text { schools }\end{array}$ & Shanghai, China \\
\hline Residents [70] & 16 PAHs in $\mathrm{PM}_{2.5}$ & Active sampler & $\begin{array}{l}\text { Outdoor, office, residential } \\
\text { home, dormitory }\end{array}$ & Beijing, China \\
\hline Residents [71] & 26 PAHs in $\mathrm{PM}_{2.5}$ & Active sampler & $\begin{array}{l}\text { Outdoor, residential } \\
\text { indoor }\end{array}$ & Hong Kong, China \\
\hline Residents [82] & 24 PAHs in PM & $\begin{array}{l}\text { Real- and non-real time } \\
\text { active sampler }\end{array}$ & Campus & Mexico city, Mexico \\
\hline Workers [83] & PAHs in PM & Real-time active sampler & $\begin{array}{l}\text { Indoor of bars or } \\
\text { restaurants }\end{array}$ & Santiago, Chile \\
\hline Children [84] & PAHs in PM & Real-time active sampler & School bus & California, America \\
\hline Residents [90] & 9 PAHs & Passive samplers & $\begin{array}{l}\text { Indoor and outdoor of } \\
\text { residences }\end{array}$ & $\begin{array}{l}\text { Central Appalachia, } \\
\text { America }\end{array}$ \\
\hline Pregnant women [92] & 8 PAHs in the gas phase & Fan-Lioy passive sampler & $\begin{array}{l}\text { Indoor and outdoor of } \\
\text { residences }\end{array}$ & Detroit, America \\
\hline $\begin{array}{l}\text { Pregnant women [94] } \\
\text { Asthma patients [103] }\end{array}$ & $\begin{array}{l}8 \text { PAHs in the gas phase } \\
16 \text { PAHs in } \mathrm{PM}_{2.5}\end{array}$ & $\begin{array}{l}\text { Fan-Lioy passive sampler } \\
\text { Active sampler }\end{array}$ & $\begin{array}{l}\text { Outdoor of residences } \\
\text { Ambient stations }\end{array}$ & $\begin{array}{l}\text { California, America } \\
\text { Taiwan, China }\end{array}$ \\
\hline Children [104] & $4,5,6$ rings PAHs in PM & $\begin{array}{l}\text { Real- and non-real time } \\
\text { active sampler }\end{array}$ & $\begin{array}{l}\text { A center station and } \\
\text { residences }\end{array}$ & California, America \\
\hline Residents [105] & 16 PAHs in $\mathrm{PM}_{2.5}$ & Active sampler & Ambient stations & Taiwan, China \\
\hline Young females [106] & 9 PAHs in PM & Active sampler & $\begin{array}{l}\text { Indoor and outdoor of } \\
\text { residences }\end{array}$ & Kraków, Poland \\
\hline
\end{tabular}

Table 2. Previous studies of PAH exposure measured by personal sampling.

\begin{tabular}{|c|c|c|c|}
\hline Subjects & PAHs Phase and Number & Sampler Type & Area \\
\hline 348 Pregnant females [72] & 9 PAHs in $\mathrm{PM}_{2.5}$ & Active sampler & New York, America \\
\hline 224 Residents [73] & 16 PAHs in $\mathrm{PM}_{2.5}$ & Active sampler & Wuhan and Zhuhai, China \\
\hline 126 Residents [74] & 15 PAHs in PM and gas phases & Active sampler & Taiyuan, China \\
\hline 80 Elderly [75] & 12 PAHs in $\mathrm{PM}_{10}$ & Active sampler & Tianjin, China \\
\hline 72 Asthmatic children [76] & LMW- and HMW-PAHs & Active sampler & Montreal, Canada \\
\hline 46 Residents [77] & 16 PAHs in $\mathrm{PM}_{2 \cdot 5}$ & Active sampler & Hong Kong, China \\
\hline 6 Residents [78] & 19 PAHs in $\mathrm{PM}_{2 \cdot 5}$ & Active sampler & Southern West Africa \\
\hline 2 Security guards [79] & 24 PAHs in $\mathrm{PM}_{2.5}$ & Active sampler & Beijing, China \\
\hline Commuters [80] & 9 PAHs in $\mathrm{PM}_{2 \cdot 5}$ & Active sampler & California, America \\
\hline Commuters [81] & 19 PAHs in $\mathrm{PM}_{2 \cdot 5}$ & Active sampler & Beijing, China \\
\hline 11 Firefighters [91] & 32 PAHs & Active and passive sampler & Stockholm, Sweden \\
\hline 22 Pregnant females [93] & $\begin{array}{l}51 \text { PAHs in passive sampler, } \\
20 \text { PAHs in active sampler }\end{array}$ & Passive sampler & New York, America \\
\hline 72 Firefighters [96] & 14 PAHs & Passive sampler & Florida, America \\
\hline
\end{tabular}

\subsection{Modeling Work}

Modeling is a low labor-intensive and cost-less alternative for the exposure evaluation of a population on an individual, which can offset the spatial-temporal restrictions of environmental monitoring and the research burden of personal sampling. The procedure of the model is to screen out exposure-relevant variables by backward or forward regression methods and combine them with exposure data through an appropriate statistical relationship form. Aquilina et al. [107] compared the predictive ability of multiple statis- 
tical approaches, including a linear regression model, a time-activity weighted model, a univariate general linear model, and machine learning techniques, namely, decision trees and neural networks, to individual exposure. In addition, the predictable ability of the estimation models can be verified by several statistics parameters [108]. For example, the coefficient of determination can measure the variability caused by a dependent variable to the measured values; the index of agreement can estimate the variation of the predicted values around the observed mean; the root mean squared errors can calculate the total average difference between the measured versus modeled values; and, the Pearson's coefficient can indicate the collinearity between the observed and predicted values.

Basic concentration data for exposure evaluation can be generated from outdoor monitoring, microenvironmental measuring, and personal sampling. Outdoor monitoring data are the most available and common data source for human exposure prediction [103]. The land-use model combines the land-use type, topographic parameters, and traffic features to generate regional air pollution levels. Noth et al. [104] performed a land-use regression to estimate the outdoor exposure level of 4-6 ring PAHs of children by the ambient level collected at a center station. The dependent variables were filtered based on the estimated effect and statistical significance of each parameter. The model fit was verified by the leave-one-out cross-validation, which measures the total average difference between the observed and predicted values. The final model revealed robustness and explained $81 \%$ of the between-house variability and $18 \%$ of the within-house variability based on the home outdoor level. A geological information system (GIS) is a typical spatial interpolation model that uses the concentration of known monitoring points to infer the concentration of unknown monitoring points, among which Kriging interpolation is the most representative spatial interpolation model. Lee et al. [105] predicted the individual exposure of $\mathrm{PM}_{2.5}$-bound PAHs by the simulated outdoor PAH level, which was refined to a high spatial resolution of 0.001 degrees with a GIS mapping approach. The estimated exposure data revealed a good correlation of $0.729(p<0.01)$ with that obtained from personal sampling. Some studies established exposure evaluation models based on microenvironmental and/or personal sampling work. Choi et al. [106] established an exposure predictive model for pregnant females based on personal, indoor, and outdoor monitoring data and found that indoor pollution closely reflects short-term exposure, while PAH exposure (Pyr and 8 carcinogenic PAHs) during the whole gestational period is more closely correlated with the outdoor pollution level. Wu et al. [101] successfully constructed regression models to estimate personal PAH exposures by coupling real-time PAH exposure, GPS-tracking time-activity data, and other exposure-related elements. The predicted data showed a correlation coefficient of 0.58 for daily exposures for all subjects, 0.61 for subject-dependent personal exposures, and 0.75 for subject-dependent exposures in different microenvironments. Based on a review of current studies, the successful modeling of outdoor exposure has been conducted, while studies of indoor environments still demonstrate a large gap. Although indoor environments contain contributions from indoor emissions and outdoor infiltration, current studies have mainly been focused on the outdoor contributions. The modeling of the indoor fraction has been limited because it ignores the diversity of the indoor microenvironments and simplifies the indoor impacting factors such as the deposition of pollutants, indoor air exchange, and building characteristics. Although many studies have explored the exposure features of microenvironments such as households, workplaces, and traffic, such results are restricted to similar exposure settings. Therefore, there is an urgent need to refine the research site and carry out general modeling work for a microenvironment exposure estimation.

\section{Conclusions}

This study summarized the evaluation methods for human inhalation exposure to PAHs, a group of toxic and ubiquitous compounds. External exposure utilizes environmental concentration coupling to describe human exposure, which can be measured under different spatial resolutions. Environmental monitoring focuses on ambient and other 
microenvironments by stationary samplers and can provide ample information on the exposure features of specific locations. Personal sampling is participant-based mobile monitoring, which is the most accurate approach to measure individual exposure without time-spatial restrictions. Human-exposed PAHs can be captured through an active sampler, which can provide a reliable and detailed description of PAHs in the gas and/or particulate phase, or passive samplers, which feature light weight, low user burden, and low cost while requiring qualified calibration. Time-activity patterns are a significant source of exposure parameters and can help to trace the exposure source and behavior and quantify the exposure level supported by time-activity diaries or GPSs.

Modeling work is generally applied to predict human exposure to PAHs by combining the exposure concentration with various exposure parameters by appropriate statistical approaches. It is significant to maintain a balance between the fitness and predictability power of the model. Furthermore, such work has successfully established ambient concentrations, while detailed modeling targeting various microenvironments, especially indoor microenvironments, is expected to be fulfilled to describe personal exposure more accurately.

Author Contributions: Conceptualization, methodology, X.Z. and N.T.; investigation, formal analysis, writing — original draft preparation, X.Z.; writing — review and editing, supervision, funding acquisition, N.T.; validation, L.Y., H.Z., W.X., Y.W. (Yan Wang), P.B., L.Z., K.H., A.T. and Y.W. (Yongjie Wei) All authors have read and agreed to the published version of the manuscript.

Funding: This work was supported by the Environment Research and Technology Development Fund (5-1951) of the Environmental Restoration and Conservation Agency of Japan; the Sumitomo Foundation, Japan (183115); the Bilateral Open Partnership Joint Research Projects of the Japan Society for the Promotion of Science, Japan (JPJSBP120219914); the CHOZEN Project of Kanazawa University, Japan; and the cooperative research programs of the Institute of Nature and Environmental Technology, Kanazawa University, Japan (20014-19, 20062).

Institutional Review Board Statement: Not applicable.

Informed Consent Statement: Not applicable.

Data Availability Statement: Data sharing not applicable.

Conflicts of Interest: The authors declare no conflict of interest.

\section{Abbreviations}

$\begin{array}{ll}\text { 5MC } & \text { 5-methylchrysene } \\ \text { Ace } & \text { Acenaphthene } \\ \text { Acy } & \text { Acenaphthylene } \\ \text { Ant } & \text { Anthracene } \\ \text { BaA } & \text { benz }[a] \text { anthracene } \\ \text { BaP } & \text { benzo }[a] \text { pyrene } \\ \text { BbF } & \text { benzo }[b] \text { fluoranthene } \\ \text { BcF } & \text { benzo[c]fluorene } \\ \text { BghiP } & \text { benzo[ghi]perylene } \\ \text { BjF } & \text { benzo[j]fluoranthene } \\ \text { BkF } & \text { benzo }[k] \text { fluoranthene } \\ \text { Chr } & \text { Chrysene } \\ \text { CPP } & \text { cyclopenta }[c, d] \text { pyrene } \\ \text { DBA } & \text { dibenz }[a, h] \text { anthracene } \\ \text { DeP } & \text { dibenzo }[a, e] \text { pyrene } \\ \text { DhP } & \text { dibenzo }[a, h] \text { pyrene } \\ \text { DIP } & \text { dibenzo }[a, l] \text { pyrene } \\ \text { DiP } & \text { dibenzo }[a, i] \text { pyrene } \\ \text { Fle } & \text { fluorene } \\ \text { FR } & \text { fluoranthene } \\ \text { GIS } & \text { geological information system } \\ \text { GPS } & \text { global positioning system } \\ \end{array}$




$\begin{array}{ll}\text { HMW-PAHs } & \text { polycyclic aromatic hydrocarbons with low high molecular weight } \\ \text { IDP } & \text { indeno[1,2,3-cd]pyrene } \\ \text { LMW-PAHs } & \text { polycyclic aromatic hydrocarbons with low molecular weight } \\ \text { MMW-PAHs } & \begin{array}{l}\text { polycyclic aromatic hydrocarbons with middle molecular weight } \\ \text { naphthalene }\end{array} \\ \text { NaP } & \text { polycyclic aromatic hydrocarbons } \\ \text { PAHs } & \text { phenanthrene } \\ \text { Phe } & \text { particulate matter } \\ \text { PM } & \text { polyurethane foam } \\ \text { PUF } & \text { pyrene } \\ \text { Pyr } & \end{array}$

\section{References}

1. Kim, K.-H.; Jahan, S.A.; Kabir, E.; Brown, R.J. A review of airborne polycyclic aromatic hydrocarbons (PAHs) and their human health effects. Environ. Int. 2013, 60, 71-80. [CrossRef] [PubMed]

2. Yang, L.; Suzuki, G.; Zhang, L.L.; Zhou, Q.Y.; Zhang, X.; Xing, W.L.; Shima, M.; Yoda, Y.; Nakatsubo, R.; Hiraki, T.; et al. The Characteristics of Polycyclic Aromatic Hydrocarbons in Different Emission Source Areas in Shenyang, China. Int. J. Environ. Res. Public Health 2019, 16, 2817. [CrossRef]

3. Zhang, J.; Yang, L.; Mellouki, A.; Chen, J.; Chen, X.; Gao, Y.; Jiang, P.; Li, Y.; Yu, H.; Wang, W. Atmospheric PAHs, NPAHs, and OPAHs at an urban, mountainous, and marine sites in Northern China: Molecular composition, sources, and ageing. Atmos. Environ. 2018, 173, 256-264. [CrossRef]

4. Rogge, W.F.; Hildemann, L.M.; Mazurek, M.A.; Cass, G.R.; Simoneit, B.R.T. Sources of fine organic aerosol. 2. Noncatalyst and catalyst-equipped automobiles and heavy-duty diesel trucks. Environ. Sci. Technol. 1993, 27, 636-651. [CrossRef]

5. Abdel-Shafy, H.I.; Mansour, M.S. A review on polycyclic aromatic hydrocarbons: Source, environmental impact, effect on human health and remediation. Egypt. J. Pet. 2016, 25, 107-123. [CrossRef]

6. Srogi, K. Monitoring of environmental exposure to polycyclic aromatic hydrocarbons: A review. Environ. Chem. Lett. 2007, 5, 169-195. [CrossRef]

7. Xing, W.L.; Zhang, L.L.; Yang, L.; Zhou, Q.Y.; Zhang, X.; Toriba, A.; Hayakawa, K.; Tang, N. Characteristics of PM2.5-Bound Polycyclic Aromatic Hydrocarbons and Nitro-Polycyclic Aromatic Hydrocarbons at A Roadside Air Pollution Monitoring Station in Kanazawa, Japan. Int. J. Environ. Res. Public Health 2020, 17, 805. [CrossRef] [PubMed]

8. Ravindra, K.; Sokhi, R.; Van Grieken, R. Atmospheric polycyclic aromatic hydrocarbons: Source attribution, emission factors and regulation. Atmos. Environ. 2008, 42, 2895-2921. [CrossRef]

9. Khalili, N.R.; Scheff, P.A.; Holsen, T.M. PAH source fingerprints for coke ovens, diesel and, gasoline engines, highway tunnels, and wood combustion emissions. Atmos. Environ. 1995, 29, 533-542. [CrossRef]

10. Tang, N.; Hattori, T.; Taga, R.; Igarashi, K.; Yang, X.; Tamura, K.; Kakimoto, H.; Mishukov, V.F.; Toriba, A.; Kizu, R.; et al. Polycyclic aromatic hydrocarbons and nitropolycyclic aromatic hydrocarbons in urban air particulates and their relationship to emission sources in the Pan-Japan Sea countries. Atmos. Environ. 2005, 39, 5817-5826. [CrossRef]

11. Torres, S.; Merino, C.; Paton, B.; Correig, X.; Ramírez, N. Biomarkers of Exposure to Secondhand and Thirdhand Tobacco Smoke: Recent Advances and Future Perspectives. Int. J. Environ. Res. Public Health 2018, 15, 2693. [CrossRef] [PubMed]

12. Idowu, O.; Semple, K.T.; Ramadass, K.; O'Connor, W.; Hansbro, P.; Thavamani, P. Beyond the obvious: Environmental health implications of polar polycyclic aromatic hydrocarbons. Environ. Int. 2019, 123, 543-557. [CrossRef] [PubMed]

13. World Health Organization. IARC Some Non-heterocyclic Polycyclic Aromatic Hydrocarbons and Some Related Exposures. In IARC Monographs on the Evaluation of Carcinogenic Risks to Humans; WHO Press: Lyon, France, 2010; Volume 92.

14. Gale, S.L.; Noth, E.M.; Mann, J.; Balmes, J.; Hammond, S.K.; Tager, I.B. Polycyclic aromatic hydrocarbon exposure and wheeze in a cohort of children with asthma in Fresno, CA. J. Expo. Sci. Environ. Epidemiol. 2012, 22, 386-392. [CrossRef] [PubMed]

15. Burstyn, I.; Boffetta, P.; Heederik, D.; Partanen, T.; Kromhout, H.; Svane, O.; Langård, S.; Frentzel-Beyme, R.; Kauppinen, T.; Stücker, I.; et al. Mortality from Obstructive Lung Diseases and Exposure to Polycyclic Aromatic Hydrocarbons among Asphalt Workers. Am. J. Epidemiol. 2003, 158, 468-478. [CrossRef]

16. Downward, G.S.; Hu, W.; Rothman, N.; Reiss, B.; Wu, G.; Wei, F.; Chapman, R.S.; Portengen, L.; Qing, L.; Vermeulen, R. Polycyclic Aromatic Hydrocarbon Exposure in Household Air Pollution from Solid Fuel Combustion among the Female Population of Xuanwei and Fuyuan Counties, China. Environ. Sci. Technol. 2014, 48, 14632-14641. [CrossRef]

17. Kilpatrick, D.J. Investigating the Relationship of COPD, Lung Cancer, and Polycyclic Aromatic Hydrocarbons from Ambient Air Pollution. Ph.D. Thesis, University of South Carolina, Columbia, SC, USA, 2019.

18. Jeng, H.A.C.; Chao, M.R.; Lin, W.Y.; Pan, C.H. Semen quality and sperm DNA damage associa-revised-final-finalted with oxidative stress in relation to exposure to polycyclic aromatic hydrocarbons. J. Environ. Sci. Health. Part A 2018, 53, 1221-1228. [CrossRef]

19. Luderer, U.; Christensen, F.; Johnson, W.O.; She, J.; Ip, H.S.S.; Zhou, J.; Alvaran, J.; Krieg, E.F.; Kesner, J.S. Associations between urinary biomarkers of polycyclic aromatic hydrocarbon exposure and reproductive function during menstrual cycles in women. Environ. Int. 2017, 100, 110-120. [CrossRef] 
20. Yin, S.; Tang, M.; Chen, F.; Li, T.; Liu, W. Environmental exposure to polycyclic aromatic hydrocarbons (PAHs): The correlation with and impact on reproductive hormones in umbilical cord serum. Environ. Pollut. 2017, 220, 1429-1437. [CrossRef]

21. Choi, H.; Jedrychowski, W.; Spengler, J.; Camann, D.E.; Whyatt, R.M.; Rauh, V.; Tsai, W.-Y.; Perera, F.P. International Studies of Prenatal Exposure to Polycyclic Aromatic Hydrocarbons and Fetal Growth. Environ. Health Perspect. 2006, 114, 1744-1750. [CrossRef]

22. Delhommelle, J. Recent developments in molecular simulation: A Study of the Effects of Environmental Polycyclic Aromatic Hydrocarbons on Birth Outcomes in Poland. Mol. Simul. 2010, 36, 497. [CrossRef]

23. Perera, F.P.; Tang, D.; Wang, S.; Vishnevetsky, J.; Zhang, B.; Diaz, D.; Camann, D.; Rauh, V. Prenatal Polycyclic Aromatic Hydrocarbon (PAH) Exposure and Child Behavior at Age 6-7 Years. Environ. Health Perspect. 2012, 120, 921-926. [CrossRef]

24. U.S. Environmental Protection Agency. Compendium Method TO-13A, Determination of Polycyclic Aromatic Hydrocarbons (PAHs) in Ambient Air Using Gas Chromatography/Mass Spectrometry (GC/MS); Center for Environmental Research Information Office of Research and Development: Cincinnati, OH, USA, 1999.

25. European Commission. Commission recommendation of 4 February 2005 on the further investigation into the levels of polycyclic aromatic hydrocarbons in certain foods. Off. J. Eur. Union 2006, 34, $43-45$.

26. Ministry of Ecology and Environment of the People's Republic of China. Chinese Ambient Air Quality Standard GB 3095-2012; China Environmental Science Press: Beijing, China, 2012.

27. European Commission. Directive 2004/107/EC of the European Parliament and of the Council of 15/12/2004 relating to arsenic, cadmium, mercury, nickel and polycyclic aromatic hydrocarbons in ambient air. Off. J. Eur. Union 2005, 23, 3-16.

28. Zhang, L.L.; Yang, L.; Zhou, Q.Y.; Zhang, X.; Xing, W.L.; Wei, Y.J.; Hu, M.; Zhao, L.X.; Toriba, A.; Hayakawa, K.; et al. Size distribution of particulate polycyclic aromatic hydrocarbons in fresh combustion smoke and ambient air: A review. J. Environ. Sci. 2020, 88, 370-384. [CrossRef]

29. Yang, X.-Y.; Okada, Y.; Tang, N.; Matsunaga, S.; Tamura, K.; Lin, J.-M.; Kameda, T.; Toriba, A.; Hayakawa, K. Long-range transport of polycyclic aromatic hydrocarbons from China to Japan. Atmos. Environ. 2007, 41, 2710-2718. [CrossRef]

30. Tang, N.; Hakamata, M.; Sato, K.; Okada, Y.; Yang, X.; Tatematsu, M.; Toriba, A.; Kameda, T.; Hayakawa, K. Atmospheric behaviors of polycyclic aromatic hydrocarbons at a Japanese remote background site, Noto peninsula, from 2004 to 2014 . Atmos. Environ. 2015, 120, 144-151. [CrossRef]

31. Yang, L.; Tang, N.; Matsuki, A.; Takami, A.; Hatakeyama, S.; Kaneyasu, N.; Nagato, E.G.; Sato, K.; Yoshino, A.; Hayakawa, K. A Comparison of Particulate-Bound Polycyclic Aromatic Hydrocarbons Long-Range Transported from the Asian Continent to the Noto Peninsula and Fukue Island, Japan. Asian J. Atmos. Environ. 2018, 12, 369-376. [CrossRef]

32. Zhang, X.; Zhang, L.L.; Yang, L.; Zhou, Q.Y.; Xing, W.L.; Toriba, A.; Hayakawa, K.; Wei, Y.J.; Tang, N. Characteristics of Polycyclic Aromatic Hydrocarbons (PAHs) and Common Air Pollutants at Wajima, a Remote Background Site in Japan. Int. J. Environ. Res. Public Health 2020, 17, 957. [CrossRef] [PubMed]

33. Zhang, L.L.; Yang, L.; Zhou, Q.Y.; Zhang, X.; Xing, W.L.; Zhang, H.; Toriba, A.; Hayakawa, K.; Tang, N. Impact of the COVID19 Outbreak on the Long-range Transport of Particulate PAHs in East Asia. Aerosol Air Qual. Res. 2020, 20, 2035-2046. [CrossRef]

34. Zhang, H.; Zhang, L.L.; Yang, L.; Zhou, Q.Y.; Zhang, X.; Xing, W.L.; Hayakawa, K.; Toriba, A.; Tang, N. Impact of COVID19 Outbreak on the Long-Range Transport of Common Air Pollutants in KUWAMS. Chem. Pharm. Bull. 2021, 69, 237-245. [CrossRef] [PubMed]

35. World Health Organization. 9 Out of 10 People Worldwide Breathe Polluted Air, But More Countries Are Taking Action. Available online: https:/ / www.who.int/news/item/02-05-2018-9-out-of-10-people-worldwide-breathe-polluted-air-but-morecountries-are-taking-action (accessed on 5 March 2021).

36. U.S. Environmental Protection Agency. USEPA Exposure Factors Handbook Chapter 6: Inhalation Rates. In Exposure Factors Handbook, 2011 ed.; National Center for Environmental Assessment: Washington, DC, USA, 2015; pp. 15-21.

37. Rengarajan, T.; Rajendran, P.; Nandakumar, N.; Lokeshkumar, B.; Rajendran, P.; Nishigaki, I. Exposure to polycyclic aromatic hydrocarbons with special focus on cancer. Asian Pac. J. Trop. Biomed. 2015, 5, 182-189. [CrossRef]

38. Burkart, K.; Nehls, I.; Win, T.; Endlicher, W. The carcinogenic risk and variability of particulate-bound polycyclic aromatic hydrocarbons with consideration of meteorological conditions. Air Qual. Atmos. Health 2013, 6, 27-38. [CrossRef]

39. U.S. Environmental Protection Agency USEPA. Exposure Factors Handbook, 2011 ed.; National Center for Environmental Assessment: Washington, DC, USA, 2011; pp. 1-1466.

40. Li, T.; Wang, Y.; Hou, J.; Zheng, D.; Wang, G.; Hu, C.; Xu, T.; Cheng, J.; Yin, W.; Mao, X.; et al. Associations between inhaled doses of PM2.5-bound polycyclic aromatic hydrocarbons and fractional exhaled nitric oxide. Chemosphere 2019, 218, 992-1001. [CrossRef]

41. Bocskay, K.A.; Tang, D.; Orjuela, M.A.; Liu, X.; Warburton, D.P.; Perera, F.P. Chromosomal Aberrations in Cord Blood Are Associated with Prenatal Exposure to Carcinogenic Polycyclic Aromatic Hydrocarbons. Cancer Epidemiol. Biomark. Prev. 2005, 14, 506-511. [CrossRef]

42. Herbstman, J.B.; Tang, D.; Zhu, D.; Qu, L.; Sjödin, A.; Li, Z.; Camann, D.; Perera, F.P. Prenatal Exposure to Polycyclic Aromatic Hydrocarbons, Benzo[a]pyrene-DNA Adducts, and Genomic DNA Methylation in Cord Blood. Environ. Health Perspect. 2012, 120, 733-738. [CrossRef] [PubMed] 
43. Choi, Y.-H.; Kim, J.H.; Hong, Y.-C. CYP1A1 genetic polymorphism and polycyclic aromatic hydrocarbons on pulmonary function in the elderly: Haplotype-based approach for gene-environment interaction. Toxicol. Lett. 2013, 221, 185-190. [CrossRef] [PubMed]

44. Wang, L.; Zhao, Y.; Liu, X.; Huang, T.; Wang, Y.; Gao, H.; Ma, J. Cancer risk of petrochemical workers exposed to airborne PAHs in industrial Lanzhou City, China. Environ. Sci. Pollut. Res. 2015, 22, 19793-19803. [CrossRef]

45. Wang, Y.; Wang, T.; Xu, M.; Yu, H.; Ding, C.; Wang, Z.; Pan, X.; Li, Y.; Niu, Y.; Yan, R.; et al. Independent effect of main components in particulate matter on DNA methylation and DNA methyltransferase: A molecular epidemiology study. Environ. Int. 2020, 134, 105296. [CrossRef] [PubMed]

46. Chen, L.; Hu, G.; Fan, R.; Lv, Y.; Dai, Y.; Xu, Z. Association of PAHs and BTEX exposure with lung function and respiratory symptoms among a nonoccupational population near the coal chemical industry in Northern China. Environ. Int. 2018, 120, 480-488. [CrossRef]

47. Zhou, Y.; Sun, H.; Xie, J.; Song, Y.; Liu, Y.; Huang, X.; Zhou, T.; Rong, Y.; Wu, T.; Yuan, J.; et al. Urinary Polycyclic Aromatic Hydrocarbon Metabolites and Altered Lung Function in Wuhan, China. Am. J. Respir. Crit. Care Med. 2016, 193, 835-846. [CrossRef]

48. Fernández, S.F.; Pardo, O.; Pastor, A.; Yusà, V.; Vento, M.; Cernada, M.; Gormaz, M.; Kuligowski, J.; Sánchez, A.; Torres, E.; et al. Biomonitoring of polycyclic aromatic hydrocarbons in the urine of lactating mothers: Urinary levels, association with lifestyle factors, and risk assessment. Environ. Pollut. 2021, 268, 115646. [CrossRef]

49. Campo, L.; Fustinoni, S.; Buratti, M.; Cirla, P.E.; Martinotti, I.; Foà, V. Unmetabolized Polycyclic Aromatic Hydrocarbons in Urine as Biomarkers of Low Exposure in Asphalt Workers. J. Occup. Environ. Hyg. 2007, 4, 100-110. [CrossRef]

50. Van Rooij, J.G.M.; Veeger, M.M.S.; Bodelier-Bade, M.M.; Scheepers, P.T.J.; Jongeneelen, F.J. Smoking and dietary intake of polycyclic aromatic hydrocarbons as sources of interindividual variability in the baseline excretion of 1-hydroxypyrene in urine. Int. Arch. Occup. Environ. Health 1994, 66, 55-65. [CrossRef] [PubMed]

51. Lafontaine, M.; Champmartin, C.; Simon, P.; Delsaut, P.; Funck-Brentano, C. 3-Hydroxybenzo[a]pyrene in the urine of smokers and non-smokers. Toxicol. Lett. 2006, 162, 181-185. [CrossRef]

52. Palazzi, P.; Hardy, E.M.; Appenzeller, B.M. Biomonitoring of children exposure to urban pollution and environmental tobacco smoke with hair analysis - A pilot study on children living in Paris and Yeu Island, France. Sci. Total. Environ. 2019, 665, 864-872. [CrossRef] [PubMed]

53. Toriba, A.; Kuramae, Y.; Chetiyanukornkul, T.; Kizu, R.; Makino, T.; Nakazawa, H.; Hayakawa, K. Quantification of polycyclic aromatic hydrocarbons (PAHs) in human hair by HPLC with fluorescence detection: A biological monitoring method to evaluate the exposure to PAHs. Biomed. Chromatogr. 2003, 17, 126-132. [CrossRef] [PubMed]

54. Palazzi, P.; Mezzache, S.; Bourokba, N.; Hardy, E.M.; Schritz, A.; Bastien, P.; Emond, C.; Li, J.; Soeur, J.; Appenzeller, B.M. Exposure to polycyclic aromatic hydrocarbons in women living in the Chinese cities of BaoDing and Dalian revealed by hair analysis. Environ. Int. 2018, 121, 1341-1354. [CrossRef]

55. Oliveira, M.; Duarte, S.; Delerue-Matos, C.; Pena, A.; Morais, S. Exposure of nursing mothers to polycyclic aromatic hydrocarbons: Levels of un-metabolized and metabolized compounds in breast milk, major sources of exposure and infants' health risks. Environ. Pollut. 2020, 266, 115243. [CrossRef] [PubMed]

56. Acharya, N.; Gautam, B.; Subbiah, S.; Rogge, M.M.; Anderson, T.A.; Gao, W. Polycyclic aromatic hydrocarbons in breast milk of obese vs normal women: Infant exposure and risk assessment. Sci. Total. Environ. 2019, 668, 658-667. [CrossRef]

57. Pulkrabova, J.; Stupak, M.; Svarcova, A.; Rössner, P.; Rossnerova, A.; Ambroz, A.; Sram, R.; Hajslova, J. Relationship between atmospheric pollution in the residential area and concentrations of polycyclic aromatic hydrocarbons (PAHs) in human breast milk. Sci. Total. Environ. 2016, 562, 640-647. [CrossRef]

58. Carrizo, D.; Domeño, C.; Nerín, I.; Alfaro, P.; Nerín, C. Atmospheric pressure solid analysis probe coupled to quadrupole-time of flight mass spectrometry as a tool for screening and semi-quantitative approach of polycyclic aromatic hydrocarbons, nitropolycyclic aromatic hydrocarbons and oxo-polycyclic aromatic hydrocarbons in complex matrices. Talanta 2015, 131, 175-184. [CrossRef] [PubMed]

59. Santos, P.M.; Campo, L.; Olgiati, L.; Polledri, E.; Sánchez, M.D.N.; Fustinoni, S. Development of a method to profile 2- to 4-ring polycyclic aromatic hydrocarbons in saliva samples from smokers and non-smokers by headspace-solid-phase microextraction-gas chromatography-triple quadrupole tandem mass spectrometry. J. Chromatogr. B 2020, 1152, 122273. [CrossRef]

60. Santos, P.M.; Sánchez, M.D.N.; Pavón, J.L.P.; Cordero, B.M.; Fernández, R.V. Liquid-liquid extraction-programmed temperature vaporizer-gas chromatography-mass spectrometry for the determination of polycyclic aromatic hydrocarbons in saliva samples. Application to the occupational exposure of firefighters. Talanta 2019, 192, 69-78. [CrossRef] [PubMed]

61. Pei, L.; Zhao, M.; Xu, J.; Li, A.; Luo, K.; Li, R.; Yang, M.; Xu, Q. Associations of ambient fine particulate matter and its constituents with serum complement C3 in a panel study of older adults in China. Environ. Pollut. 2019, 252, 1019-1025. [CrossRef] [PubMed]

62. Wu, Y.; Zhang, N.; Wang, Y.; Ren, Y.; Yuan, Z.; Li, N. Concentrations of polycyclic aromatic hydrocarbons in street dust from bus stops in Qingyang city: Estimates of lifetime cancer risk and sources of exposure for daily commuters in Northwest China. Environ. Pollut. 2020, 266, 115222. [CrossRef] [PubMed]

63. Ramírez, N.; Cuadras, A.; Rovira, E.; Marcé, R.M.; Borrull, F. Risk Assessment Related to Atmospheric Polycyclic Aromatic Hydrocarbons in Gas and Particle Phases near Industrial Sites. Environ. Health Perspect. 2011, 119, 1110-1116. [CrossRef] [PubMed] 
64. Zhang, J.; Liu, W.; Xu, Y.; Cai, C.; Liu, Y.; Tao, S.; Liu, W. Distribution characteristics of and personal exposure with polycyclic aromatic hydrocarbons and particulate matter in indoor and outdoor air of rural households in Northern China. Environ. Pollut. 2019, 255, 113176. [CrossRef]

65. Du, W.; Chen, Y.; Zhu, X.; Zhong, Q.; Zhuo, S.; Liu, W.; Huang, Y.; Shen, G.; Tao, S. Wintertime air pollution and health risk assessment of inhalation exposure to polycyclic aromatic hydrocarbons in rural China. Atmos. Environ. 2018, 191, 1-8. [CrossRef]

66. He, K.; Xu, H.; Feng, R.; Shen, Z.; Li, Y.; Zhang, Y.; Sun, J.; Zhang, Q.; Yang, L.; Liu, P.; et al. Characteristics of indoor and personal exposure to particulate organic compounds emitted from domestic solid fuel combustion in rural areas of northwest China. Atmos. Res. 2021, 248, 105181. [CrossRef]

67. Zhu, Y.; Yang, L.; Meng, C.; Yuan, Q.; Yan, C.; Dong, C.; Sui, X.; Yao, L.; Yang, F.; Lu, Y.; et al. Indoor/outdoor relationships and diurnal/nocturnal variations in water-soluble ion and PAH concentrations in the atmospheric PM2.5 of a business office area in Jinan, a heavily polluted city in China. Atmos. Res. 2015, 153, 276-285. [CrossRef]

68. Zhang, L.L.; Morisaki, H.; Wei, Y.J.; Li, Z.G.; Yang, L.; Zhou, Q.Y.; Zhang, X.; Xing, W.L.; Hu, M.; Shima, M.; et al. PM2.5-bound polycyclic aromatic hydrocarbons and nitro-polycyclic aromatic hydrocarbons inside and outside a primary school classroom in Beijing: Concentration, composition, and inhalation cancer risk. Sci. Total. Environ. 2020, 705, 135840. [CrossRef] [PubMed]

69. Zhang, L.L.; Tokuda, T.; Yang, L.; Zhou, Q.Y.; Zhang, X.; Xing, W.L.; Wu, Q.; Zhou, Z.; Chen, R.; Kameda, T.; et al. Characteristics and Health Risks of Particulate Polycyclic Aromatic Hydrocarbons and Nitro-polycyclic Aromatic Hydrocarbons at Urban and Suburban Elementary Schools in Shanghai, China. Asian J. Atmos. Environ. 2019, 13, 266-275. [CrossRef]

70. Chen, Y.; Li, X.; Zhu, T.; Han, Y.; Lv, D. PM2.5-bound PAHs in three indoor and one outdoor air in Beijing: Concentration, source and health risk assessment. Sci. Total. Environ. 2017, 586, 255-264. [CrossRef]

71. Chen, X.-C.; Chuang, H.-C.; Ward, T.J.; Tian, L.; Cao, J.-J.; Ho, S.S.-H.; Lau, N.-C.; Hsiao, T.-C.; Yim, S.H.; Ho, K.-F. Indoor, outdoor, and personal exposure to PM2.5 and their bioreactivity among healthy residents of Hong Kong. Environ. Res. 2020, 188, 109780. [CrossRef]

72. Tonne, C.C.; Whyatt, R.M.; Camann, D.E.; Perera, F.P.; Kinney, P.L. Predictors of personal polycyclic aromatic hydrocarbon exposures among pregnant minority women in New York City. Environ. Health Perspect. 2004, 112, 754-759. [CrossRef]

73. Mu, G.; Fan, L.; Zhou, Y.; Liu, Y.; Ma, J.; Yang, S.; Wang, B.; Xiao, L.; Ye, Z.; Shi, T.; et al. Personal exposure to PM2.5-bound polycyclic aromatic hydrocarbons and lung function alteration: Results of a panel study in China. Sci. Total. Environ. 2019, 684, 458-465. [CrossRef] [PubMed]

74. Duan, X.; Wang, B.; Zhao, X.; Shen, G.; Xia, Z.; Huang, N.; Jiang, Q.; Lu, B.; Xu, D.; Fang, J.; et al. Personal inhalation exposure to polycyclic aromatic hydrocarbons in urban and rural residents in a typical northern city in China. Indoor Air 2014, 24, 464-473. [CrossRef] [PubMed]

75. Han, B.; You, Y.; Liu, Y.; Xu, J.; Zhou, J.; Zhang, J.; Niu, C.; Zhang, N.; He, F.; Ding, X.; et al. Inhalation cancer risk estimation of source-specific personal exposure for particulate matter-bound polycyclic aromatic hydrocarbons based on positive matrix factorization. Environ. Sci. Pollut. Res. 2019, 26, 10230-10239. [CrossRef]

76. Smargiassi, A.; Goldberg, M.S.; Wheeler, A.J.; Plante, C.; Valois, M.-F.; Mallach, G.; Kauri, L.M.; Shutt, R.; Bartlett, S.; Raphoz, M.; et al. Associations between personal exposure to air pollutants and lung function tests and cardiovascular indices among children with asthma living near an industrial complex and petroleum refineries. Environ. Res. 2014, 132, 38-45. [CrossRef] [PubMed]

77. Fan, Z.; Pun, V.C.; Chen, X.-C.; Hong, Q.; Tian, L.; Ho, S.S.-H.; Lee, S.-C.; Tse, L.A.; Ho, K.-F. Personal exposure to fine particles (PM2.5) and respiratory inflammation of common residents in Hong Kong. Environ. Res. 2018, 164, 24-31. [CrossRef]

78. Xu, H.; Léon, J.-F.; Liousse, C.; Guinot, B.; Yoboué, V.; Akpo, A.B.; Adon, J.; Ho, K.F.; Ho, S.S.H.; Li, L.; et al. Personal exposure to PM2.5 emitted from typical anthropogenic sources in southern West Africa: Chemical characteristics and associated health risks. Atmos. Chem. Phys. Discuss. 2019, 19, 6637-6657. [CrossRef]

79. Wei, Y.; Han, I.-K.; Hu, M.; Shao, M.; Zhang, J.; Tang, X. Personal exposure to particulate PAHs and anthraquinone and oxidative DNA damages in humans. Chemosphere 2010, 81, 1280-1285. [CrossRef]

80. Lovett, C.; Shirmohammadi, F.; Sowlat, M.H.; Sioutas, C. Commuting in Los Angeles: Cancer and Non-cancer Health Risks of Roadway, Light-Rail and Subway Transit Routes. Aerosol Air Qual. Res. 2018, 18, 2363-2374. [CrossRef]

81. Yan, C.; Zheng, M.; Yang, Q.; Zhang, Q.; Qiu, X.; Zhang, Y.; Fu, H.; Li, X.; Zhu, T.; Zhu, Y. Commuter exposure to particulate matter and particle-bound PAHs in three transportation modes in Beijing, China. Environ. Pollut. 2015, 204, 199-206. [CrossRef]

82. Amador-Muñoz, O.; Martínez-Domínguez, Y.; Gómez-Arroyo, S.; Peralta, O. Current situation of polycyclic aromatic hydrocarbons (PAH) in PM2.5 in a receptor site in Mexico City and estimation of carcinogenic PAH by combining non-real-time and real-time measurement techniques. Sci. Total. Environ. 2020, 703, 134526. [CrossRef] [PubMed]

83. Muñoz, C.; Droppelmann, A.; Erazo, M.; Aceituno, P.; Orellana, C.; Parro, J.; Mesias, S.; Marchetti, N.; Navas-Acien, A.; Iglesias, V. Occupational exposure to polycyclic aromatic hydrocarbons: A cross-sectional study in bars and restaurants in Santiago, Chile. Am. J. Ind. Med. 2016, 59, 887-896. [CrossRef]

84. Sabin, L.D.; Behrentz, E.; Winer, A.M.; Jeong, S.; Fitz, D.R.; Pankratz, D.V.; Colome, S.D.; Fruin, S.A. Characterizing the range of children's air pollutant exposure during school bus commutes. J. Expo. Sci. Environ. Epidemiol. 2004, 15, 377-387. [CrossRef] 
85. Ott, W.R.; Wilson, N.; Klepeis, N.E.; Switzer, P. Real-time monitoring of polycyclic aromatic hydrocarbons and respirable suspended particles from environmental tobacco smoke in a home. In Proceedings of the International Symposium on Measurement of Toxic and Related Air Pollutants; U.S. Environmental Protection Agency and A\&WM International Symposium: Durham, NC, USA, 1994; pp. 887-892.

86. Childers, J.W.; Witherspoon, C.L.; Smith, L.B.; Pleil, J.D. Real-Time and Integrated Measurement of Potential Human Exposure to Particle-Bound Polycyclic Aromatic Hydrocarbons (PAHs) from Aircraft Exhaust. Environ. Health Perspect. 2000, $2,853-862$. [CrossRef]

87. Fang, T.B.; Lu, Y. Personal real-time air pollution exposure assessment methods promoted by information technological advances. Ann. GIS 2012, 18, 279-288. [CrossRef]

88. Morawska, L.; Thai, P.K.; Liu, X.; Asumadu-Sakyi, A.; Ayoko, G.; Bartonova, A.; Bedini, A.; Chai, F.; Christensen, B.; Dunbabin, M.; et al. Applications of low-cost sensing technologies for air quality monitoring and exposure assessment: How far have they gone? Environ. Int. 2018, 116, 286-299. [CrossRef]

89. Davis, C.S.; Fellin, P.; Otson, R. A Review of Sampling Methods for Polyaromatic Hydrocarbons in Air. JAPCA 1987, 37, 1397-1408. [CrossRef]

90. Hendryx, M.; Wang, S.; Romanak, K.A.; Salamova, A.; Venier, M. Personal exposure to polycyclic aromatic hydrocarbons in Appalachian mining communities. Environ. Pollut. 2020, 257, 113501. [CrossRef] [PubMed]

91. Strandberg, B.; Julander, A.; Sjöström, M.; Lewné, M.; Akdeva, H.K.; Bigert, C. Evaluation of polyurethane foam passive air sampler (PUF) as a tool for occupational PAH measurements. Chemosphere 2018, 190, 35-42. [CrossRef]

92. Johnson, M.M.; Williams, R.; Fan, Z.; Lin, L.; Hudgens, E.; Gallagher, J.; Vette, A.; Neas, L.; Özkaynak, H. Participant-based monitoring of indoor and outdoor nitrogen dioxide, volatile organic compounds, and polycyclic aromatic hydrocarbons among MICA-Air households. Atmos. Environ. 2010, 44, 4927-4936. [CrossRef]

93. Dixon, H.M.; Scott, R.P.; Holmes, D.; Calero, L.; Kincl, L.D.; Waters, K.M.; Camann, D.E.; Calafat, A.M.; Herbstman, J.B.; Anderson, K.A. Silicone wristbands compared with traditional polycyclic aromatic hydrocarbon exposure assessment methods. Anal. Bioanal. Chem. 2018, 410, 3059-3071. [CrossRef]

94. Masri, S.; Li, L.; Dang, A.; Chung, J.H.; Chen, J.-C.; Fan, Z.-H.; Wu, J. Source characterization and exposure modeling of gas-phase polycyclic aromatic hydrocarbon (PAH) concentrations in Southern California. Atmos. Environ. 2018, 177, 175-186. [CrossRef]

95. O'Connell, S.G.; Kincl, L.D.; Anderson, K.A. Silicone Wristbands as Personal Passive Samplers. Environ. Sci. Technol. 2014, 48, 3327-3335. [CrossRef] [PubMed]

96. Baum, J.L.; Bakali, U.; Killawala, C.; Santiago, K.M.; Dikici, E.; Kobetz, E.N.; Solle, N.S.; Deo, S.; Bachas, L.; Daunert, S. Evaluation of silicone-based wristbands as passive sampling systems using PAHs as an exposure proxy for carcinogen monitoring in firefighters: Evidence from the firefighter cancer initiative. Ecotoxicol. Environ. Saf. 2020, 205, 111100. [CrossRef] [PubMed]

97. Fan, Z.; Jung, K.H.; Lioy, P.J. Development of a Passive Sampler to Measure Personal Exposure to Gaseous PAHs in Community Settings. Environ. Sci. Technol. 2006, 40, 6051-6057. [CrossRef] [PubMed]

98. Anderson, K.A.; Points, G.L.; Donald, C.E.; Dixon, H.M.; Scott, R.P.; Wilson, G.; Tidwell, L.G.; Hoffman, P.D.; Herbstman, J.B.; O'Connell, S.G. Preparation and performance features of wristband samplers and considerations for chemical exposure assessment. J. Expo. Sci. Environ. Epidemiol. 2017, 27, 551-559. [CrossRef] [PubMed]

99. Mo, Y.; Li, N.; Xu, C.Y.; Xu, D.Q. Review of survey method for human time-activity pattern and its application in the exposure assessment of air pollutants. Chin. J. Prev. Med. 2018, 52, 675-680.

100. Nethery, E.; Wheeler, A.J.; Fisher, M.; Sjödin, A.; Li, Z.; Romanoff, L.C.; Foster, W.; Arbuckle, T.E. Urinary polycyclic aromatic hydrocarbons as a biomarker of exposure to PAHs in air: A pilot study among pregnant women. J. Expo. Sci. Environ. Epidemiol. 2011, 22, 70-81. [CrossRef]

101. Wu, J.; Tjoa, T.; Li, L.; Jaimes, G.; Delfino, R.J. Modeling personal particle-bound polycyclic aromatic hydrocarbon (pb-pah) exposure in human subjects in Southern California. Environ. Health 2012, 11, 47. [CrossRef] [PubMed]

102. Li, M.; Gao, S.; Lu, F.; Tong, H.; Zhang, H. Dynamic Estimation of Individual Exposure Levels to Air Pollution Using Trajectories Reconstructed from Mobile Phone Data. Int. J. Environ. Res. Public Health 2019, 16, 4522. [CrossRef]

103. Lee, S.-W.; Huang, Y.-C.; Lin, C.-Y.; Huang, H.-Y.; Liu, C.-W.; Hsieh, M.-T.; Lee, C.-L.; Chung, W.-Y.; Chung, K.F.; Wang, C.-H.; et al. Impact of Annual Exposure to Polycyclic Aromatic Hydrocarbons on Acute Exacerbation Frequency in Asthmatic Patients. J. Asthma Allergy 2021, 14, 81-90. [CrossRef]

104. Noth, E.M.; Hammond, S.K.; Biging, G.S.; Tager, I.B. A spatial-temporal regression model to predict daily outdoor residential PAH concentrations in an epidemiologic study in Fresno, CA. Atmos. Environ. 2011, 45, 2394-2403. [CrossRef]

105. Lee, C.-L.; Huang, H.-C.; Wang, C.-C.; Sheu, C.-C.; Wu, C.-C.; Leung, S.-Y.; Lai, R.-S.; Lin, C.-C.; Wei, Y.-F.; Lai, I.-C.; et al. A new grid-scale model simulating the spatiotemporal distribution of PM2.5-PAHs for exposure assessment. J. Hazard. Mater. 2016, 314, 286-294. [CrossRef] [PubMed]

106. Choi, H.; Zdeb, M.; Perera, F.; Spengler, J. Estimation of chronic personal exposure to airborne polycyclic aromatic hydrocarbons. Sci. Total. Environ. 2015, 527-528, 252-261. [CrossRef]

107. Aquilina, N.J.; Delgado-Saborit, J.M.; Gauci, A.P.; Baker, S.; Meddings, C.; Harrison, R.M.; Delgado-Saborit, J.M. Comparative Modeling Approaches for Personal Exposure to Particle-Associated PAH. Environ. Sci. Technol. 2010, 44, 9370-9376. [CrossRef]

108. Willmott, C.J. On the Validation of Models. Phys. Geogr. 1981, 2, 184-194. [CrossRef] 